\title{
Information and Communication Technologies: Views of Canadian College Students and "Excellent" Professors
}

\author{
Catherine Fichten ${ }^{1,2}$, Mary Jorgensen ${ }^{2}$, Alice Havel ${ }^{1,2}$, Laura King ${ }^{2,4}$, Alex Lussier ${ }^{2}$, Jennison Asuncion ${ }^{2}$, Jillian Budd $^{2}$, \\ Mai Nhu Nguyen ${ }^{2}$, Rhonda Amsel ${ }^{3}$ \\ ${ }^{1}$ Dawson College, Montreal, Canada \\ ${ }^{2}$ Adaptech Research Network, Montreal, Canada \\ ${ }^{3}$ McGill University, Montreal, Canada \\ ${ }^{4}$ Cégep André-Laurendeau, LaSalle, Canada \\ Correspondence: Catherine Fichten, Adaptech Research Network, Montreal, Quebec, H3Z 1A4, Canada.
}

Received: June 5, 2018 Accepted: June 25, $2018 \quad$ Online Published: June 26, 2018

doi:10.11114/jets.v6i9.3390 URL: https://doi.org/10.11114/jets.v6i9.3390

\begin{abstract}
We explored students' perspectives about their professors' use of information and communication technologies (ICTs) and compared these to the views of professors deemed by their students to be excellent in their use of ICTs. 311 students completed an online questionnaire and nominated up to three of their professors who used technology in a way that worked well for them. We conducted semi-structured interviews with 114 of the nominated professors, who also completed a checklist of technologies used in their teaching. There are some technologies that students said worked well for them that not many professors used in their teaching, such as online tests / quizzes, podcasts, and clickers. However, there were some technologies that both students and professors agreed did not facilitate learning, such as digital text books, blogs and chat rooms. Finally, there was also agreement among professors and students about technologies that did help with learning, such as e-mails, videos and online submission of assignments.

Both student and professor perspectives need to be considered when evaluating what technologies work in teaching. Future research should examine why students prefer certain technologies. In addition, reasons for the discrepancies between professors and student views needs further investigation.
\end{abstract}

Keywords: information and communication technologies (ICT), college, post-secondary student versus faculty perspectives, personal technologies, PowerPoint, course/learning management systems

\section{Introduction}

Information and communication technology (ICT) use by faculty in colleges and universities in North America is ubiquitous and entire journals and magazines (e.g., Campus Technology, Educause Review) are devoted to promoting their use. Here we examine the views of college students and of professors nominated by their students as excellent in their use of information and communication technologies (ICTs). What ICTs are frequently used in teaching? How well do these work, as perceived by students? In what ways are the perspectives of students and of professors nominated as excellent in their use of ICTs similar? How do their views differ?

Post-secondary institutions world-wide are under increasing pressure to introduce new technology into their curriculum, in order to help students develop the technological knowledge and skills that are necessary in the current job market (Hue \& Ab Jalil, 2013). Many researchers also reported that technology is a necessary resource for improving the quality of teaching and learning (Plump, Anderson, Law, \& Quale, 2009). The importance of technology in post-secondary education was further highlighted by Sahin-Kizil (2011) who found that the use of technology in courses resulted in numerous positive outcomes for students, including higher levels of motivation, facilitating access to information, and making the course resources easier to use.

\subsection{Professors' Perceptions About ICT Use}

\subsubsection{Technologies Used by Professors}

There is an extensive literature about what technologies professors actually use in their teaching. For example, a study 
by Buchanan, Sainter and Saunders (2013), with a sample of 114 professors, found that the ten most frequently used technologies were: links to online library resources; online audio / video podcasts from other sources; formative online testing; online audio / video podcasts created by the professors themselves; discussion boards for class discussions; discussion boards for frequently asked questions; blogs with the goal of encouraging reflection on learning; Wikis; blogs for micropublishing; and online tests. An increase in the popularity of recorded lectures has also been noted (O’Callaghan, Neumann, Jones, \& Creed, 2017).

The popularity of social networks, such as Facebook and Twitter, in academe has increased. Yet, there is minimal empirical literature on faculty experiences with the educational use of social networks (Veletsianos \& Kimmons, 2012). Among existing studies, Caldwell (2015) found that only 18\% of professors used social network sites in their teaching, although almost 50\% were willing to use these more extensively. Zakharov, Horton, Reid, Willis, and Attardo (2017) provided an explanation for the low frequency of social media use by exploring the experiences of 126 professors. They found that a variety of barriers exist to the use of social media in teaching: reliability, complexity, lack of support, inadequate professional development, time requirements, and legal issues.

\subsubsection{Proficiency}

The limited research on professor proficiency in teaching with technology shows that professors were more likely to use technology in their courses if they had a greater degree of confidence in their ability to use this (Howard \& Mozejko, 2015). These researchers also found no significant differences between male and female professors in their level of confidence in their ability to use technology.

\subsubsection{Use of Personal Technology in Class}

There are no universally accepted guidelines that dictate the appropriate use of mobile technologies in class (Lindroth \& Bergquist, 2010). This has resulted in a culture of uncertainty, in which neither professors nor students understand what constitutes the appropriate use of laptops and other mobile devices in class (Kay \& Lauricella, 2011; Santos, Bocheco, \& Habak, 2018).

Some professors do not allow students to use their laptops and mobile technologies in class at all (Young, 2006). This has the potential to create conflict between professors and their students, since students indicated that being allowed to use their personal technologies in class was important (Alkahtani, Ahmad, Darmoul, Samman, Al-zabidi, \& Matraf, 2016).

Other professors choose to ignore how students use their laptops and mobile technologies in class. There are two risks associated with this approach: (1) the potential of facilitating off-task behavior (Fried, 2008) and (2) possible distractions associated with the use of personal technologies in class (Sana, Weston, \& Cepeda, 2013). Indeed, not only do students using personal technologies do more poorly academically (Kuznekoff, Munz, \& Titsworth, 2015), but students sitting near classmates who were using their personal technologies were distracted as well (Sana, Weston, \& Cepeda, 2013). However, Sharp, Hemmings, Kay, Murphy and Elliott (2016) found that when students engaged in off-task behavior in class, they did not necessarily use technology.

Another approach has been to accept and embrace the use of laptops in class in an attempt to use technology as a tool to support pedagogical practices (Gay, Stefanone, Grace-Martin, \& Hembrooke, 2001). This was found to be the approach that kept students most engaged in course-related tasks (Kay \& Lauricella, 2011).

\subsection{Students' Perceptions About ICT Use}

\subsubsection{Technologies Used by Professors.}

Karsenti, Meunier, Villeneuve, and Raby (2011) examined 10,266 students' experiences with ICTs. They found that over 80\% of students reported that the use of ICTs - particularly e-mail - improved communication with professors and peers. Overall, $83 \%$ of students said the use of ICTs facilitated their learning and over $2 / 3$ reported that the use of ICTs helped them learn course material faster and increased their interest in course content. When asked about the use of specific ICTs, most students reported that PowerPoint had many advantages if it was used effectively (Karsenti et al., 2011). In this study only about $60 \%$ of students said that discussion forums facilitated their learning, although most liked having access to online resources, such as the course outline, course notes, web sites, grades, and assignments completed by students during previous semesters.

Access to course notes and PowerPoints online can allow students to concentrate better in class, to engage in more active listening and to use the notes to prepare for exams (J.B., personal communication, November 2015). Students who like to be prepared for class can print the PowerPoint before class and take notes beside the slide, as is common at academic conferences. Moreover, students with disabilities can benefit from PowerPoints available before class. For example, students with hearing impairments can "speech (lip) read" the professor rather than having to look down to take notes (M.N., personal communication, February 2014). Similarly, students with visual impairments and learning disabilities are able to add to the notes on their laptops or other portable devices (J.B., personal communication, 
November 2015). Furthermore, poor readers and students whose mother tongue is not the language of instruction can read the slides before class to identify key concepts and ideas. In addition, students typically indicate that online course notes and PowerPoints help them study if they missed a class or if they have taken poor quality notes (Hill, Arford, Lubitow, \& Smollin, 2012).

\subsubsection{Use of Personal Technology in Class}

A recent Harris Poll showed that, "Laptops are still the most commonly used mobile device for school work" and that, "more students use smartphones regularly for school work than use tablets" (Harris Poll, 2015). Baker, Lusk, and Neuhauser (2012) reported on how students used their personal technology in class: students sent text messages, with almost $25 \%$ reporting that they sent one text message every class, and another $15 \%$ saying that they sent $5-10$ text messages in class every week. However, approximately $33 \%$ of students said they rarely or never sent text messages in class. The authors pointed out that students are more likely to check their text messages than to actually send them. Surprisingly, $80 \%$ of the students in their sample said that they rarely or never used laptops in class.

\subsection{Student vs. Professor Perceptions on ICT Use in Teaching}

We were able to find only a handful of studies which directly compared ICT related views of college students and professors. Among these, only the investigation by Venkatesh et al. (2016) asked the same questions of both 14,928 students and 2,626 professors about a broad-based variety of technologies (e.g., email, course management systems, blogs). Their investigation showed that, overall, students are more satisfied with courses where lecture-related ICTs are used (e.g., PowerPoint, videos), whereas professors felt that effective teaching was related to social constructivist uses of ICTs (e.g., blogs, wikis). Other studies examined mainly the use of specific technologies, such as smartphones, laptops, and MP3 players (Baker et al., 2012) and social networking applications (Caldwell, 2015).

Baker et al.'s (2012) study of 882 students and 96 professors found that the two groups do not agree either on the appropriate use of technology in class or on policies dictating the use of technology in class. For example, $93 \%$ of professors reported that they have the right to tell students that they 'must' turn off their cell phones in class; only $66 \%$ of students agreed that professors had the right to do so. There were also discrepancies between students' and professors' perspectives on the usefulness of laptops in the classroom. Eighty percent of students - but only $62 \%$ of professors agreed with the statement that laptops are useful and that they should be allowed in the classroom. Students were also less likely to find web browsing of non-course related content disruptive than professors and they were less likely to disapprove of answering e-mails during class and more likely to believe that professors should allow for quiet, non-disruptive use of laptops in class. Similar discrepancies were reported by Santos, Bocheco, and Habak, 2018).

Baker et al. (2012) reported that $50 \%$ of professors felt that there should be college-wide policies about the use of smartphones in class and, indeed, some universities have policies about the use of personal technologies in class. Alternately, a variety of regulations were proposed by Cheong, Shuter, and Suwinyattichaiporn, (2016). Suggestions for managing distractions include discussing the consequences of mobile technology use for non-course related activities and asking those using their personal technologies to sit in a separate area of the classroom (Sana et al., 2013).

A study of 49 students and 11 professors by Caldwell (2015) found that $46 \%$ of professors reported a willingness to use social network sites more extensively in their teaching; $65 \%$ of students said that they would be willing to do so. Students and professors both reported that social network sites could facilitate group discussions, but their perspectives differed on use of social network sites for individual communications. Professors did not see the use of social network sites as a substitute for in person meetings or phone conversations with students; rather they saw these as a tool to deliver course information, such as announcements and reminders. Privacy and confidentiality concerns related to the use of social network sites for pedagogical purposes were noted by students and professors.

\subsection{The Present Study}

Our goal is to add to the literature by exploring not only Canadian junior / community college students' views about their professors' use of ICTs - and how effective they found these ICTs were for their learning - but also the views of professors deemed by these same students to be excellent users of ICTs in their teaching. This comparison is important. Faculty can benefit from identifying which of their students' needs are - and are not - being met. It could also be helpful for professors to know what ICTs professors deemed excellent in their instructional use of technology by their students actually use. We were interested in using a comparative framework because consistent views about what works well by "excellent professors" and by students may result in increased student motivation and engagement.

\section{Method}

\subsection{Participants}

All participants took part in a larger investigation. This consists of a study which only examined students' experiences with 
the use of ICTs in post-secondary education (Fichten, et al., 2015) and a study which examined professors' perspectives (Jorgensen et al., 2018). Here we use a comparative framework to compare and contrast professor and student views.

\subsubsection{Students}

The sample consisted of 311 students (126 male, 183 female, 2 declined to say). They had completed a minimum of 1 semester of studies at one of two large public junior / community colleges in Montreal. Students were enrolled in either a 2 year academic or a 3 year career/technical program. Students were enrolled in 3 programs: (a) Arts $(n=55$; includes disciplines such as literature, interior design, fine arts), (b) Social Science $(n=157$; includes psychology, business administration, economics), and (c) Science ( $n=96$; includes nursing, chemistry, mathematics). Three students did not indicate their program. Mean age was 20.50 (range $=18-44$ ). There were no significant differences between males and females on either age or field of study.

\subsubsection{Professors}

Of the 131 professors contacted, 114 (46 females, 68 males) from the same two junior / community colleges as the students participated. They were nominated by an average of 4 students for their use of instructional technology in a way that worked well for them. Professors taught in 3 different programs: 39 professors taught in Social Science, 43 in Science, and 32 in Arts programs. Approximately half of each group $(n=62)$ taught in an academic and half $(n=52)$ in a career/technical program, with the exception of Arts, since one of the junior / community colleges did not have any Arts career/technical programs. The average number of their years teaching at a college was 9.33 years (median $=6.89$, range $<1$ to 38 ).

\subsection{Measures}

\subsubsection{Checklist of ICTs Used in Teaching}

An extensive checklist of technologies was completed by both students and professors (available in Table 1). This listing was based on the literature and was developed in meetings with team members and partner representatives. Professors checked those technologies that they used in their teaching. Students responded (Yes/No) to the question "Check the technologies that instructors at your college use that usually worked well for you."

\subsubsection{Perceived Proficiency in the Use of Technology}

Both students and professors completed two 6-point Likert-scaled items ( 1 = strongly disagree, 6 = strongly agree):

- I am very knowledgeable in the use of computer technologies

- I am very comfortable using computer technologies.

Students - Use of personal technology in class

Students completed two 6-point Likert-scaled items:

- In general, my professors allow me to use (my personal) technologies in class.

- I like courses which allow me to use (my personal) technologies in class (e.g., laptop, tablet).

Professors - Use of personal technology in class

Professors completed one 6-point Likert-scaled item:

- I allow my students to use (their personal) computer technology in class.

\subsection{Procedure}

The research protocol was approved by the Research Ethics Board of one of the two colleges. First, we administered a brief demographic questionnaire to 1384 students enrolled in 56 compulsory courses in two large public junior / community colleges in Montreal. These were administered to obtain contact information for students over age 18 who had completed at least one semester of college studies and who were willing to participate in future studies. Between October and December of 2014, students who indicated that we may contact them were directed to a web page which included a description of the study and a consent form; this mentioned the $\$ 20$ honorarium offered. The "continue" button brought students to the online survey. Of the 437 students whom we contacted by email, 311 (71\%) completed the 20 minute online questionnaire about their college experiences with instructional uses of ICTs (see Fichten et al., 2015).

The 311 students were also asked to nominate up to three professors whom they believed used ICTs well in their teaching. Based on students' responses, we attempted to select professors with the most nominations at each of the two participating colleges. We also tried to select at least 10 professors from Social Science, from Science, and from Arts in both academic and career/technical programs in both colleges. Therefore, there were a minimum of 20 professors from each program of study, except for Science ( $n=19$ because relatively few professors were nominated) and Arts, because one college did not have a career/technical Arts program. We had interviewed 5 additional nominated professors while 
waiting for professors to respond - we decided to include their data.

In 2015, we used e-mail to contact professors within each category, from the most to least frequently nominated to set up an interview. When we did not receive a response to our email, we telephoned. We attempted to contact each professor a maximum of three times or until the professor specifically told us that they were not interested in participating. Once an appointment time was set we met with the professor, who signed the consent form. Professors were interviewed (see Jorgensen, et al., 2018), and they then completed the Checklist of ICTs Used in Teaching, followed by the use of personal technology in class item and the perceived expertise and comfort in the use of technology questions.

\section{Results}

\subsection{Professors' Use of Technology Versus Students' Perceived Effectiveness}

Table 1 presents the results from the Checklist of ICTs Used in Teaching. It is organized into six sections. Within each we indicate the number (and percent) of professors who said they used the technology and the number (and percent) of students who said that this technology worked well for them. We used Chi-square tests to examine differences between the proportion of professors who indicated using the technology and the proportion of student responses indicating that technology worked well for them. Given the large number of tests, we applied a Bonferroni correction to the alpha level; this shows that only items where $p=0.001$ or better are significant. Any item where the Chi-square was significant was considered to be different. Also, we generally used $=>67 \%$ as "working well."

Table 1. Professors' Use of Technology vs. Students' Report That Technology Worked Well For Them

\begin{tabular}{|c|c|c|c|c|c|c|}
\hline \multirow[t]{2}{*}{ Checklist of ICTs Used in Teaching } & \multicolumn{2}{|c|}{$\begin{array}{l}\text { Students said ICTs } \\
\text { worked well }^{\mathrm{a}}\end{array}$} & \multicolumn{2}{|c|}{$\begin{array}{l}\text { Professors said } \\
\text { they use ICTs }\end{array}$} & \multirow{2}{*}{$\begin{array}{c}\begin{array}{c}\text { Significance } \\
\text { of } X^{2}\end{array} \\
p=\end{array}$} & \multirow[t]{2}{*}{$\begin{array}{c}\text { Difference } \\
a-b\end{array}$} \\
\hline & $n$ & $\%^{\mathrm{a}}$ & $n$ & $\%^{b}$ & & \\
\hline \multicolumn{7}{|l|}{ Online course materials } \\
\hline Tests / quizzes & 156 & $86 \%$ & 44 & $39 \%$ & 0.001 & $47 \%$ \\
\hline Attendance record & 169 & $88 \%$ & 65 & $57 \%$ & 0.001 & $31 \%$ \\
\hline Calendar & 188 & $87 \%$ & 79 & $69 \%$ & 0.001 & $18 \%$ \\
\hline Digital textbooks & 52 & $63 \%$ & 54 & $47 \%$ & N.S. & $16 \%$ \\
\hline Course notes/PowerPoints & 262 & $97 \%$ & 94 & $82 \%$ & 0.001 & $15 \%$ \\
\hline Tutorials / practice exercises & 176 & $83 \%$ & 89 & $78 \%$ & N.S. & $5 \%$ \\
\hline Grades & 294 & $99 \%$ & 109 & $96 \%$ & N.S. & $3 \%$ \\
\hline Assignments & 286 & $96 \%$ & 107 & $94 \%$ & N.S. & $2 \%$ \\
\hline Web links & 216 & $86 \%$ & 103 & $90 \%$ & N.S. & $-4 \%$ \\
\hline Course outline & 277 & $94 \%$ & 114 & $100 \%$ & N.S. & $-6 \%$ \\
\hline \multicolumn{7}{|l|}{ Online Tools } \\
\hline Portfolios & 48 & $86 \%$ & 20 & $18 \%$ & 0.001 & $68 \%$ \\
\hline Podcasts & 20 & $71 \%$ & 16 & $14 \%$ & 0.001 & $57 \%$ \\
\hline Wiki sites & 54 & $74 \%$ & 25 & $22 \%$ & 0.001 & $52 \%$ \\
\hline Blogs & 57 & $61 \%$ & 22 & $19 \%$ & 0.001 & $42 \%$ \\
\hline Collaborative work online & 49 & $62 \%$ & 29 & $25 \%$ & 0.001 & $37 \%$ \\
\hline Online assignment submission & 225 & $93 \%$ & 97 & $85 \%$ & N.S. & $8 \%$ \\
\hline Videos & 174 & $84 \%$ & 91 & $80 \%$ & N.S. & $4 \%$ \\
\hline Style guides & 35 & $18 \%$ & 42 & $37 \%$ & 0.001 & $-19 \%$ \\
\hline \multicolumn{7}{|l|}{ Hardware used } \\
\hline Clickers & 57 & $73 \%$ & 19 & $17 \%$ & 0.001 & $56 \%$ \\
\hline Smart Board & 73 & $58 \%$ & 28 & $25 \%$ & 0.001 & $33 \%$ \\
\hline Computer lab & 251 & $90 \%$ & 104 & $91 \%$ & N.S. & $-1 \%$ \\
\hline Multimedia projector & 280 & $96 \%$ & 112 & $98 \%$ & N.S. & $-2 \%$ \\
\hline Computer to teach & 255 & $90 \%$ & 108 & $95 \%$ & N.S. & $-5 \%$ \\
\hline \multicolumn{7}{|l|}{ Communication tools } \\
\hline Virtual office hours & 79 & $85 \%$ & 34 & $30 \%$ & 0.001 & $55 \%$ \\
\hline Chatroom & 39 & $59 \%$ & 12 & $11 \%$ & 0.001 & $48 \%$ \\
\hline Discussion forum & 58 & $52 \%$ & 32 & $28 \%$ & 0.001 & $24 \%$ \\
\hline Instant messaging & 5 & $18 \%$ & 26 & $23 \%$ & N.S. & $-5 \%$ \\
\hline Email & 225 & $86 \%$ & 113 & $99 \%$ & 0.001 & $-13 \%$ \\
\hline \multicolumn{7}{|l|}{ Social networking } \\
\hline LinkedIn & 7 & $64 \%$ & 16 & $14 \%$ & 0.001 & $50 \%$ \\
\hline Twitter & 9 & $53 \%$ & 11 & $10 \%$ & 0.001 & $43 \%$ \\
\hline Facebook & 25 & $56 \%$ & 26 & $23 \%$ & 0.001 & $33 \%$ \\
\hline \multicolumn{7}{|l|}{ Other technologies used in class } \\
\hline Mind mapping & 37 & $71 \%$ & 12 & $11 \%$ & 0.001 & $60 \%$ \\
\hline Simulations / virtual experiments & 83 & $88 \%$ & 42 & $37 \%$ & 0.001 & $51 \%$ \\
\hline Presentation software & 293 & $98 \%$ & 104 & $91 \%$ & N.S. & $7 \%$ \\
\hline
\end{tabular}

Note. NS indicates "not significant." 


\subsubsection{Course Materials Available Online}

Table 1 shows that among online course materials which over $80 \%$ of students said worked well for them, substantially fewer professors indicated using the following: online tests/quizzes, attendance records, and calendars. Students generally felt that online tutorials / practice exercises, assignments, grades, and web links worked well for them and over $75 \%$ of professors provided these. On the other hand, less than $2 / 3$ of students felt that digital textbooks worked well for them, and somewhat fewer than $50 \%$ of professors indicated that they used these. Although almost all students indicated that online course notes or PowerPoints worked well for them, only $82 \%$ of professors posted these online.

\subsubsection{Online Tools}

Table 1 also shows that most professors used the online tools that over $80 \%$ of students said worked well for them, with the exception of portfolios, where significantly and substantially fewer professors indicated using these. Fewer than $75 \%$ of students indicated that the following worked well for them: wikis, podcasts, blogs, collaborative work online, and style guides; fewer than $40 \%$ of professors used these.

\subsubsection{Hardware Used}

Over $90 \%$ of students indicated that use of a computer lab, a multimedia projector, and a computer used to teach worked well for them and over $90 \%$ of professors used these technologies in their teaching. However, while $73 \%$ of students indicated that they liked "clickers" only $17 \%$ of professors used these. Moreover, only $58 \%$ of students indicated that use of Smart Boards (interactive whiteboards) worked well for them; only $25 \%$ of professors indicated using these.

\subsubsection{Communication Tools}

Both students (86\%) and professors (99\%) indicated that email worked well. However, while $85 \%$ of students who had experienced virtual office hours indicated that this worked well for them, only $30 \%$ of professors indicated using this. Under $60 \%$ of students indicated that chatrooms, discussion forums, and instant messaging worked well for them and under $30 \%$ of professors used these.

\subsubsection{Social Networking}

Fewer than $2 / 3$ of students indicated that LinkedIn, Twitter, or Facebook worked well for them when used by their instructors and fewer than $1 / 4$ of professors used these.

\subsubsection{Other Technologies Used to Teach in Class}

Almost $100 \%$ of students indicated that presentation software, such as PowerPoint, worked well for them and over $90 \%$ of professors used this. Although close to $90 \%$ students indicated that simulations / virtual experiments worked well for them, fewer than $40 \%$ of professors used this. In addition, slightly under $75 \%$ of students indicated that mind mapping software worked well for them, but only $11 \%$ of professors used this.

\subsection{Students' and Professors' Perceived Expertise and Comfort in the Use of Technology}

Two-way analysis of variance (ANOVA) comparisons were used to examine gender and students' and professors' perceived proficiency and level of comfort with the use of technology.

\subsubsection{Proficiency}

Means and standard deviations in Table 2 and ANOVA test results show that students' perceived knowledge ratings were significantly higher (i.e., more proficient in the use of technology) than those of professors, $F(1,418)=4.64, p=$ 0.032 . Males, in general (including professors and students), reported being more knowledgeable than did females, $F(1,418)=7.02, p=0.008$. The interaction was not significant.

Table 2. Students' and Professors' Perceived Proficiency and Comfort in Using Technology

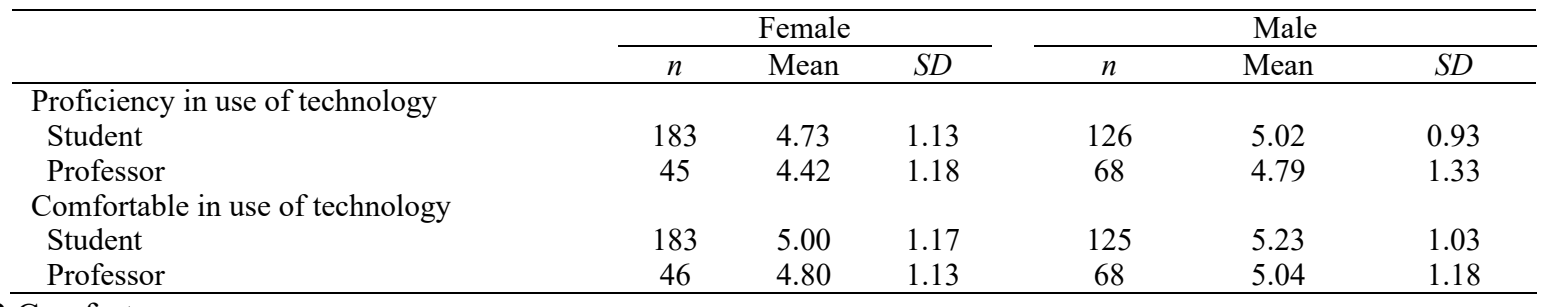

\subsubsection{Comfort}

Table 2 and ANOVA test results show no significant difference between students and professors in their perceptions of how comfortable they were using technology. The effect of gender approached significance, $F(1,418)=3.50, p=0.062$, suggesting that males felt somewhat more comfortable with technology than did females. The interaction was not significant. 


\subsection{Use of Personal Technologies in Class}

Among the 57 professors who spontaneously indicated whether they allowed their students to use personal technologies in class, $8(14 \%)$ indicated that they do not allow students to do this, $17(30 \%)$ specified that they allowed this but with limitations, and $32(56 \%)$ indicated that they allowed this with no limitations.

Figure 1 shows the relationship between students' views about using their personal technologies in class and professors' responses about whether they allowed their students to do this. Statistical analyses show the following. Students were significantly more likely to appreciate courses where professors allowed them to use their personal technology in class than they indicated that their professors, in general, allowed them to do so, (paired-samples $t$-test) $t(285)=13.98, p=$ 0.001 . The extent to which professors in this sample allowed their students to use personal technology in class was significantly greater than students' belief that, in general, their professors allowed them to do this, (independent samples $t$-test) $t(416)=7.56, p=0.001$. In addition, the t-test approached significance when we compared students' liking of courses where professors allowed them to use their personal technology in class with the agreement of professors in the present sample with the statement that they let students use their personal technology in class, (independent samples $t$-test) $t(405)=1.93, p=0.055$.

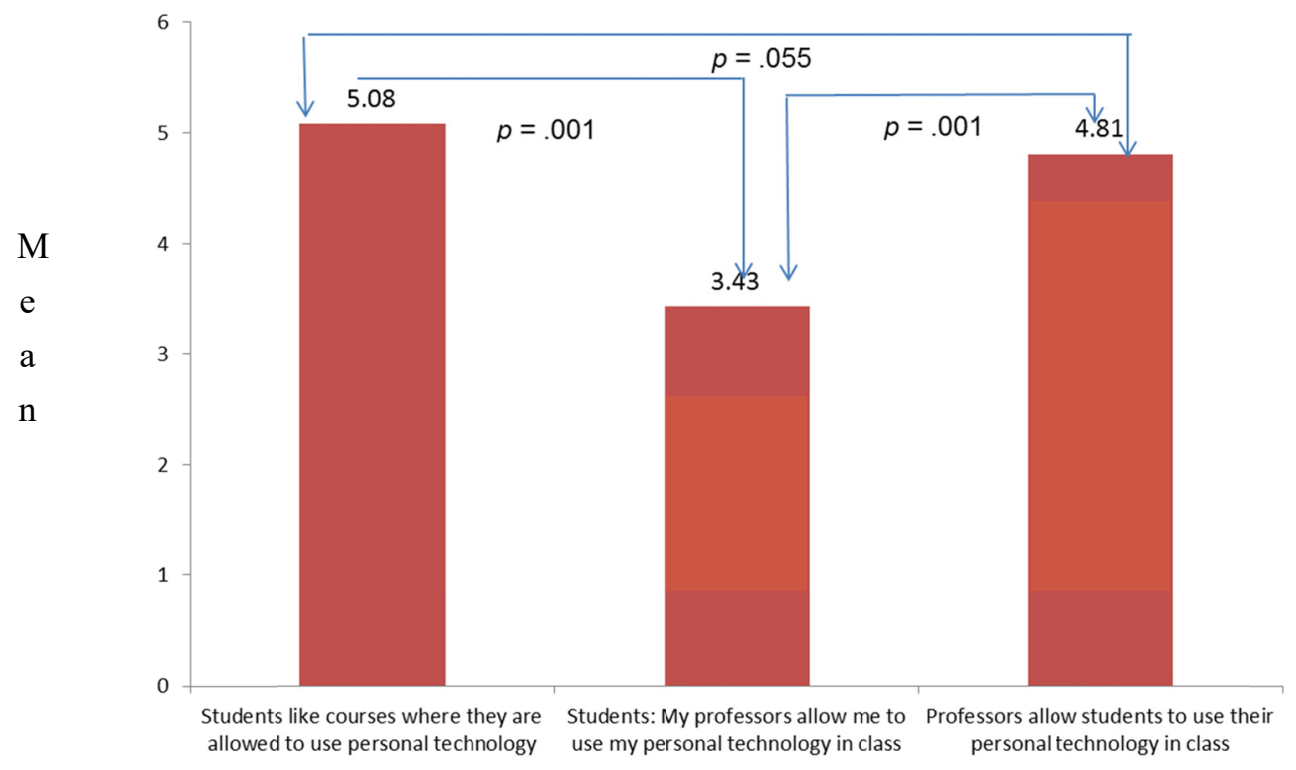

Figure 1. Students' and professors' views about allowing the use of personal technology in class

\section{Discussion}

\subsection{Use of Students' Personal Technology in Class}

Students were more likely to appreciate courses where they were allowed to use their personal technology in class than they felt that their professors, in general, allowed them to do this. The professors in our sample were more likely to allow their students to use personal technology in class than students felt that their professors, in general, did.

Student: It would be great if all professors could allow us to use laptops to take notes in class.

Consistent with the literature (Alkahtani et al., 2016; Baker et al., 2012), students liked it when their professors allowed them to use their personal technologies in class, even though research clearly shows that using mobile technologies in class often results in poorer learning and grades (Wood et al., 2011). The reticence of professors to accept the use of personal technology in class found by Baker et al. was not replicated in our study. Professors in our sample generally allowed their students to use their personal technologies in class, with the majority allowing this without any limitations.

Our findings are different from previous research. This may be due to a variety of reasons, including the growing ubiquity of such devices, the fact that our professors were nominated by their students, and that our professors were likely to be relatively young and to be users of such personal technologies themselves.

Future research should ask more specific questions about what policies professors implement regarding the use of personal technology in class. This includes asking whether professors discuss the advantages and disadvantages of the use of personal technology in class, and whether there is a dialogue between the students and the professor about what constitutes appropriate use. 


\subsection{Technologies that Worked Well for Students and Were Frequently Used by Professors}

Technologies that worked well for students and were used by most professors in our sample include: online course notes or PowerPoints, tutorials / practice exercises, grades, assignments, web links, course outlines, videos, and style guides; the use of computer labs, multimedia projectors, and computer to teach; the use of email to communicate; and the use of presentation software in class.

Student: Posting new assignments online. It was readily available the moment it was posted, so I was able to read the specifications as soon as possible.

Student: I really like when assignment instructions are available online - I never have to worry about losing them!

Professor: Do not put too much text on PowerPoint slides, do not read what is on the slides, make the slides more visual.

Professor: ... If teachers do choose to post notes it needs to be done in such a way that it is interactive so that the students have to engage in taking notes, e.g. fill in the blanks

Online videos have been shown by others, too, to be among the most frequently used technologies used by professors (Buchanan et al., 2013) and email has been found to be very useful by students (Karsenti et al., 2011). It is important to note that, consistent with Karsenti et al., virtually all students in our sample indicated that posted course notes and/or PowerPoints online worked well for them. Moreover, over $80 \%$ of nominated professors posted these, despite the frequently voiced concern that if notes and PowerPoints are posted online, students will not attend class. However, a previous study by Fichten et al. (2013) found that students self-reported that they were equally likely to attend class when course notes were and when these were not posted online. Since self-report is not actual behavior, more research is needed on how online PowerPoints and course notes influence learning and class participation.

\subsection{Technologies that Worked Poorly for Students and Were Infrequently Used by Professors}

Technologies that students felt did not facilitate learning and that professors did not use frequently include: digital textbooks, blogs, collaborative work online, chat rooms, discussion forums and social network sites.

Student: One of my professors asked us to make a (WordPress) blog and put the work we did in the course on the blog. That was extra work for not enough benefit. The only advantage is being able to see other students' blogs. I would've preferred to simply hand in my work normally. If a certain work should be visible to other students there are easy ways to do that without making everyone do a blog.

Fewer than $2 / 3$ of students indicated that digital textbooks worked well for them and under $1 / 2$ of professors indicated using these. There are many advantages to digital textbooks. For example, they are often cheaper than paper textbooks, they can be searched digitally and some can be listened to or sections can be copied. However, there are also numerous problems: some digital textbooks do not allow copying or printing and not all allow students to highlight (Fichten, Asuncion, \& Scapin, 2014). The availability of digital textbooks are on the rise (VitalSource, 2017) and more research needs to be carried out on what makes them user-friendly and cost-effective.

Our findings on the use of social network sites are similar to those of Caldwell et al. (2015), who found that only $18 \%$ of professors and 25\% of students used Facebook or other social network sites for educational purposes. Students in our study did not feel that LinkedIn, Twitter or Facebook worked well for them and professors did not use these. To quote a student, "stay out of my private life." The importance of this finding should not be overlooked, for although few professors and students currently use social network sites almost half of the professors in Caldwell's (2015) study indicated a willingness to explore their use more extensively. The key questions that emerge are: how to overcome the confidentiality and privacy concerns related to social network sites, which preoccupy both students and professors, and how to most effectively use social network sites to facilitate online discussions (Caldwell et al., 2015). Future research should examine whether course specific social network sites, such as a Facebook page dedicated to a specific class, would help avoid some of the privacy concerns.

Yet, many of our findings on technologies that worked poorly for both students were infrequently used by professors (e.g., blogs, collaborative work online, chat rooms, discussion forums) are not consistent with findings in the literature. For example, Buchanan et al. (2013) found that the top ten technologies used by professors were primarily Web 2.0 tools or online collaboration tools. Similarly, Venkatesh et al. (2016) reported that professors - but not students - felt that constructivist ICTs, such as blogs and wikis, were associated with effective instructional techniques.

Student: Group work using technologies is not a good way to have students participate. Some students don't want to work on projects at all.

Student: Submitting things to the discussion forum was nerve racking because other students could see your 
poetry assignments and other emotional writing that would have been better to be kept personal.

Although it is possible that differences in professor responses are due to different listings of technologies in our study and those of Venkatesh et al. (2016), it is also possible that the nominated professors in our study used ICTs in their teaching that the students liked, rather than those currently seen by education specialists as effective constructivist teaching tools.

\subsection{Technologies that Worked Well for Students that Professors Did Not Use}

There were some technologies that students said worked well for them that professors did not use frequently in their teaching, with the largest discrepancies involving the use of portfolios, podcasts, wiki sites, clickers (classroom response systems), virtual office hours, simulations / virtual experiments, and online test/ quizzes.

Student: Online exams are less stressful I find. When people walk out of the exam much earlier than I do, I question myself for not knowing the material as well as them, even if I do. It is just stressful for me to take an exam in a room full of people in general.

For example, more than $80 \%$ of students said that attendance records posted online worked well for them, but few professors did this. Most college courses do not provide grades for attendance. Nevertheless, some professors require that students attend a certain minimum number of classes (e.g., physical education, languages). Here students like to have an indication of how many classes they missed.

Over $85 \%$ of students reported that they liked virtual office hours. Yet, only $30 \%$ of professor reported using this. Because virtual office hours are likely to benefit both students and professors, it would be interesting to find out why professors do not use this.

While close to $90 \%$ of students felt that online tests and quizzes worked well for them, fewer than $40 \%$ of professors indicated using these. This is inconsistent with the fact that summative exams were one of the ten most frequently used technologies in the study by Buchanan et al. (2013). It is possible that the two groups in our study interpreted the question differently. Students may have found that practice tests and quizzes were helpful, while professors may have been thinking of exams administered online - where a key concern is cheating. While technologies such as LanSchool (undated) allow professors to control and/or monitor students' computers, this is easy to circumvent. Another problem with online testing revolves around "extended time" for students with certain disabilities. First, some course/learning management testing systems do not allow this. Second, sophisticated knowledge of the software is necessary to modify the time for specific students.

\subsection{Conceptualizing Similarities and Differences}

Our results suggest that, consistent with Venkatesh et al. (2016), students did not like social constructivist ICTs and the professors whom students nominated as exemplary in their use of technology generally did not report using these. What both students and professors did like is a variety of online materials that they can access whenever they wished, excluding social constructivist tools such as wikis. Online ways of communicating with professors and peers using traditional means (e.g., email, uploading attachments) were also popular.

Student: Being able to send our assignments in so we don't have any late penalties.

However, social constructivist communication tools (e.g., chat rooms, blogs, discussion forums, social media) were not popular. An important area of discrepancy between students and professors was related to student use of personal technologies such as laptops and smartphones in class. In addition, students would have liked professors to utilize a number of ICTs that are either difficult for professors to use (e.g., simulations, online exams and practice tests, online office hours) or that are unavailable or need training (e.g., portfolios, "clickers," interactive whiteboards).

\subsection{Proficiency in the Use of Technology}

Consistent with research on gender differences, showing that males are more confident than females in STEM related abilities (Kessels, Heyder, Latsch, \& Hannover, 2014), our findings show that males (students and professors combined) perceived themselves as being more knowledgeable about ICTs than did females.

It is interesting that students in our sample perceived themselves as more proficient in the use of technology than did professors. It is possible that students can feel that they are expert because they use more social media and other non-academic ICTs. But this expertise may not transfer to academic ICTs, and professors may need to teach students how to use the ICTs needed for the course (Jorgensen, et al., 2018). Nevertheless students are not homogeneous in their level of ability, so it may be helpful if professors were to add Google references or YouTube videos to show students how to use required software.

Professor: Students like to see that teachers do not necessarily always know everything about how to use 
technology; students also like to know that they can help their teachers use technology in class.

Professor: Teachers need to be willing to ask students how to use technology if they need help and should also be willing to learn from students about what technology is available that the teacher does not know about yet.

\subsection{Limitations}

Perhaps the most important limitation is that our data are based on students' and professors' self-reports. We are not able to show that any of the practices deemed useful by either or both groups actually results in superior learning or retention. It should also be noted that relatively small samples of students and professors from two public junior / community colleges were studied. Moreover, although we specifically asked the students in our sample to name those professors who used ICTs in an exemplary way in their teaching, it is likely that they also named professors whom they considered to be excellent teachers in general (Dziuban \& Moskal, 2011).

\subsection{Recommendations}

The results highlight the conclusion that both student and professor perspectives need be considered when evaluating what ICTs work in the classroom. The next step involves understanding the reasons for discrepancies between perspectives. Moreover, it is necessary to evaluate the impact of the use of specific ICTs on actual learning processes and outcomes.

Our findings suggest that professors may want to explore using the following ICTs in their teaching: online tests/quizzes, calendars, attendance records, portfolios, online polling/responsive systems, virtual office hours, as well as the possibility of simulations or virtual experiments, in both STEM and the social sciences. The following ICTs are popular both with students and faculty, and should be employed regularly: using a computer to teach; use of short videos; permitting students to submit assignments online; presentation software such as PowerPoint; using a multimedia projector; online posting of grades, assignments, course outlines, and course notes and PowerPoints.

Digital textbooks have not yet matured sufficiently to recommend their use without a paper textbook back-up. Constructivist ICTs such as blogs, collaborative work online, chatrooms, discussion forums, and instant messaging, as well as all forms of social networking were not popular among either professors or students. The reasons for this need to be explored in greater detail, but in the present context, we do not recommend their use.

Future research should examine why students like certain ICTs in courses. Does it facilitate their learning? Does it make their learning experience more enriching? Do they feel more engaged or motivated? In addition, reasons for the discrepancies between professor and student views also need further investigation. The use of a comparative framework needs to go beyond this exploratory study. After all, the two populations share the same learning environment, whether it is in the traditional classroom, in online learning or in a blended environment.

\section{References}

Alkahtani, M., Ahmad, A., Darmoul, S., Samman, S., Al-zabidi, A., \& Matraf, K. B. (2016). Multitasking trends and impact on education: A literature review. International Journal of Social, Behavioral, Educational, Economic, Business and Industrial Engineering, 10(3), 987-993.

Baker, W. M., Lusk, E. J., \& Neuhauser, K. L. (2012). On the use of cell phones and other electronic devices in the classroom: Evidence from a survey of faculty and students. Journal of Education for Business, 87(5), 275-289. https://doi.org/10.1080/08832323.2011.622814

Buchanan, T., Sainter, P., \& Saunders, G. (2013). Factors affecting faculty use of learning technologies: Implications for models of technology adoption. Journal of Computing in Higher Education, 25(1), 1-11. https://doi.org/10.1007/s12528-013-9066-6

Caldwell, J. M. (2015). Going where students are: Comparing faculty and student uses and perceptions of social networking in education (Doctoral dissertation). Retrieved from http://scholar.utc.edu/cgi/viewcontent.cgi?article=1293\&context=theses

Cheong, P. H., Shuter, R., \& Suwinyattichaiporn, T. (2016). Managing student digital distractions and hyperconnectivity: Communication strategies and challenges for professional authority. Communication Education, 65(3), 272-289. https://doi.org/10.1080/03634523.2016.1159317

Dziuban, C., \& Moskal, P. (2011). A course is a course is a course: Factor invariance in student evaluation of online, blended and face-to-face learning environments. Internet and Higher Education, 14(4), 236-241. https://doi.org/10.1016/j.iheduc.2011.05.003

Fichten, C. S., Asuncion, J., \& Scapin, R. (2014). E-Learning and information and communication technologies in postsecondary education of students with disabilities: Where we are and where we're going. Proceedings of the 
17th Annual Accessing Higher Ground: Accessible Media, Web \& Technology Conference, Westminster, Colorado. Retrieved from http://accessinghigherground.org/wp/wp-content/uploads/2014/04/accessing-higher-groundRe5-2-5-pager.docx

Fichten, C. S., King, L., Jorgensen, M., Nguyen, M. N., Budd, J., Havel, A., ... Poldma, T. (2015). What do college students really want when it comes to their instructors' use of information and communication technologies (ICTs) in their teaching? International Journal of Learning, Teaching and Educational Research, 14(2), 173-191. Retrieved from http://www.ijlter.org/index.php/ijlter/article/view/522/pdf

Fichten, C. S., Nguyen, M. N., King, L., Barile, M., Havel, A., Mimouni, Z., ... Asuncion, J. (2013). Information and communication technology profiles of college students with learning disabilities and adequate and very poor readers. Journal of Education and Learning, 2(1), 176-188. https://doi.org/10.5539/jel.v2n1p176

Fried, C. B. (2008). In-class laptop use and its effects on student learning. Computers \& Education, 50(3), 906-914. doi:10.1016/j.compedu.2006.09.00

Gay, G., Stefanone, M., Grace-Martin, M., \& Hembrooke, H. (2001). The effects of wireless computing in collaborative learning environments. International Journal of Human-Computer Interaction, 13(2), 257-276. https://doi.org/10.1207/S15327590IJHC1302_10

Harris, P. (2015, June). Pearson student mobile device survey 2015: National report: College students. Retrieved from http://www.pearsoned.com/wp-content/uploads/2015-Pearson-Student-Mobile-Device-Survey-College.pdf

Hill, A., Arford, T., Lubitow, A., \& Smollin, L. (2012). "I'm ambivalent about it": The dilemmas of PowerPoint. Teaching Sociology, 40(3), 242-256.

Howard, S. K., \& Mozejko, A. (2015). Teachers: technology, change and resistance. In M. Henderson \& G. Romeo (Eds.), Teaching and digital technologies: Big issues and critical questions (pp. 307-317). Port Melbourne, Australia: Cambridge University Press.

Hue, L. T., \& Jalil, H. A., (2013). Attitudes towards ICT integration into curriculum and usage among university lecturers in Vietnam. International Journal of Instruction, 6(2), 53-66. Retrieved from https://www.researchgate.net/publication/288407376_Attitudes_towards_ICT_Integration_into_Curriculum_and_ Usage_among_University_Lecturers_in_Vietnam

Jorgensen, M., Havel, A., Fichten, C., King, L., Marcil, E., Lussier, A., Budd, J., \& Vitouchanskaia, C. (2018). "Simply the best": Professors nominated by students for their exemplary technology practices in teaching. Education and Information Technologies, 23(1), 193-210. https://doi.org/10.1007/s10639-017-9594-1

Karsenti, T., Meunier, H., Villeneuve, S., \& Raby, C. (2011). Usage des TIC en pédagogie universitaire : point de vue des étudiants. Revue internationale des technologies en pédagogie universitaire, 8(3), 6-19. Retrieved from http://www.erudit.org/fr/revues/ritpu/2011-v8-n3-ritpu1824085/1006396ar/

Kay, R. H., \& Lauricella, S. (2011). Unstructured vs. structured use of laptops in higher education. Journal of Information Technology Education: Innovations in Practice, 10, 33-42. https://doi.org/10.28945/1363

Kessels, U., Heyder, A., Latsch, M., \& Hannover, B. (2014). How gender differences in academic engagement relate to students' gender identity. Educational Research, 56(2), 220-229. https://doi.org/10.1080/00131881.2014.898916

Kiume, S. (2016). Top 10 online psychology experiments. Retrieved from http://psychcentral.com/blog/archives/2008/08/18/top-ten-online-psychology-experiments/

Kuznekoff, J. H., Munz, S., \& Titsworth, S. (2015). Mobile phones in the classroom: Examining the effects of texting, Twitter, and message content on student learning. Communication Education, 64(3), 344-365. https://doi.org/10.1080/03634523.2015.1038727

LanSchool (undated). LanSchool - Simple, Reliable Classroom Management. Retrieved from https://www.lenovosoftware.com/lanschool

Lindroth, T., \& Bergquist, M. (2010). Laptopers in an educational practice: Promoting the personal learning situation. Computers \& Education, 54(2), 311-320. https://doi.org/10.1016/j.compedu.2009.07.014

O’Callaghan, F. V., Neumann, D. L., Jones, L., \& Creed, P. A. (2017). The use of lecture recordings in higher education: A review of institutional, student, and lecturer issues. Education and Information Technologies, 22(1), 399-415. https://doi.org/10.1007/s10639-015-9451-z

Plump, T., Anderson, R. E., Law, N., \& Quale, A. (2009). Cross-national information and communication: Technology policies and practices in education ( $2^{\text {nd }}$ ed.). Charlotte, North Carolina: Information Age Publishing. 
Sahin-Kizil, A. (2011, June). Teachers attitudes towards information and communication teachnologies (ICT). Paper presented at the 5th International Computer \& Instructional Technologies Symposium, Elaziğ, Turkey.

Sana, F., Weston, T., \& Cepeda, N. J. (2013). Laptop multitasking hinders classroom learning for both users and nearby peers. Computers \& Education, 62, 24-31. https://doi.org/10.1016/j.compedu.2012.10.003

Santos, I. M., Bocheco, O., \& Habak, C. (2018). A survey of student and instructor perceptions of personal mobile technology usage and policies for the classroom Education and Information Technologies, 23(2), 617-632. https://doi.org/10.1007/s10639-017-9625-y

Sharp, J. G., Hemmings, B., Kay, R., Murphy, B., \& Elliott, S. (2016). Academic boredom among students in higher education: A mixed-methods exploration of characteristics, contributors and consequences. Journal of Further and Higher Education. Advance online publication. https://doi.org/10.1080/0309877X.2016.1159292

Veletsianos, G., \& Kimmons, R. (2012). Scholars and faculty members' lived experiences in online social networks. Internet and Higher Education, 16, 43-50. https://doi.org/10.1016/j.iheduc.2012.01.004

Venkatesh, V., Rabah, J., Fusaro, M., Couture, A., Varela, W., \& Alexander, K. (2016). Factors impacting university instructors' and students' perceptions of course effectiveness and technology integration in the age of web 2.0. McGill Journal of Education, 51(1), 533-562. https://doi.org/10.7202/1037358ar

VitalSource. (2017). Digital learning simplified. Retrieved from https://www.vitalsource.com

Wood. E., Zivcakova, L., Gentile, P., Archer, K., De Pasquale, D., \& Nosko, A. (2011). Examining the impact of off-task multi-tasking with technology on real-time classroom learning. Computers \& Education, 58(1), 365-374. https://doi.org/10.1016/j.compedu.2011.08.029

Young, J. R. (2006, June 2). The fight for classroom attention: professor vs. laptop. Chronicle of Higher Education, A27-A29.

Zakharov, W., Horton, A., Reid, P., Willis, J., \& Attardo, D. (2017). Social media: An integration guideline for teaching and learning in higher education. In F.-Q. Lai, \& J. D. Lehman (Eds.), Learning and knowledge analytics in open education (pp. 149-169). https://doi.org/10.1007/978-3-319-38956-1_12

\section{Copyrights}

Copyright for this article is retained by the author(s), with first publication rights granted to the journal.

This is an open-access article distributed under the terms and conditions of the Creative Commons Attribution license which permits unrestricted use, distribution, and reproduction in any medium, provided the original work is properly cited. 